\title{
Performance and physiological parameters in broilers fed different enzyme complexes
}

\section{Desempenho e parâmetros fisiológicos de frangos de corte alimentados com diferentes programas de enzimas}

\author{
Thiago dos Santos Andrade ${ }^{1 *}$; Ricardo Vianna Nunes ${ }^{2}$; Idiana Mara da Silva ${ }^{3}$; \\ Lucas Wachholz; ; Vitor Barbosa Fascina ${ }^{5}$
}

\begin{abstract}
The effects of enzyme supplementation on the performance, yield, and blood profile of broilers fed corn and soybean diets from 1 to 42 days of age were evaluated. A total of 960 male broilers were used, distributed in a completely randomized design, with six treatments and eight replications. Two diets were used: a positive control formulated to meet the birds' nutritional requirements (Diet 1) and a negative control diet with reduction of $150 \mathrm{kcal} \cdot \mathrm{kg}^{-1}$ of metabolizable energy (Diet 2) and $12 \%$ amino acid in the initial phase and $18 \%$ during the growing and finishing phases. Further diets were based on the negative control with enzymes: enzyme complex 1, composed of $125 \mathrm{~g}$ ton $^{-1}$ protease; enzyme complex 2, composed of $100 \mathrm{~g}^{-1} \mathrm{n}^{-1}$ amylase, protease, and xylanase; enzyme complex 3 , composed of $500 \mathrm{~g}$ ton $^{-1}$ amylase, protease, and xylanase; and enzyme complex 4, composed of $125 \mathrm{~g} \mathrm{ton}^{-1}$ protease and $500 \mathrm{~g}^{-1}$ ton $^{-1}$ beta-mannanase. Enzymatic supplementation did not improve performance during the initial and growing phases due to nutritional imbalance, resulting in the worst weight gain and feed conversion during the finishing phase. Carcass yield, leg yield, abdominal fat, and pancreas were altered by enzymatic supplementation. Triglyceride levels influenced abdominal fat deposition, and the serum levels of albumin and alanine aminotransferase were altered by enzymatic supplementation. Enzymatic supplementation was not effective in restoring broiler performance, carcass yield, and cuts, with changes in the serum biochemical profile of the broiler chickens.
\end{abstract}

Key words: Amylase. Metabolizable energy. Protease. Xylanase.

\section{Resumo}

Este trabalho foi realizado para avaliar os efeitos da suplementação enzimática sobre o desempenho, rendimento e perfil sanguíneo em frangos de corte alimentados com dietas de milho e soja no período de 1 a 42 dias de idade. Foram utilizados 960 machos, distribuídos em um delineamento inteiramente casualizado com seis dietas e oito repetições, sendo formuladas duas rações, o controle positivo para atender as exigências nutricionais e o controle negativo com redução de $150 \mathrm{kcal} \mathrm{kg}^{-1}$ de energia metabolizável e $12 \%$ de aminoácidos nas fases iniciais e $18 \%$ nas fases de crescimento e terminação,

' M.e em Zootecnia, Universidade Estadual do Oeste do Paraná, UNIOESTE, Marechal Cândido Rondon, PR, Brasil. E-mail: thiagoandradefoz@hotmail.com

2 Prof. Dr. Adjunto, Departamento de Zootecnia, Centro de Ciências Agrárias, UNIOESTE, Marechal Cândido Rondon, PR, Brasil. E-mail: nunesrv@hotmail.com

3 Zootecnista, UNIOESTE, Marechal Cândido Rondon, PR, Brasil. E-mail: idianams@outlook.com

4 M.e em Zootecnia, UNIOESTE, Marechal Cândido Rondon, PR, Brasil. E-mail: lucaswach@hotmail.com

5 Médico Veterinário, Dr. em Zootecnia, Representante da Empresa DSM, Produtos Nutricionais, Mairinque, SP, Brasil. E-mail: vitor.fascina@dsm.com

* Author for correpondence

Received: Nov. 28, 2016 Approved: Apr. 24, 2017 
sendo estas as dietas um e dois. As demais dietas foram à base do controle negativo com enzimas, sendo o complexo enzimático um composto por $125 \mathrm{~g}$ ton $^{-1}$ de protease; complexo enzimático dois composto por $100 \mathrm{~g} \mathrm{ton}^{-1}$ de amilase, protease e xilanase; complexo enzimático três composto por $500 \mathrm{~g} \mathrm{ton}^{-1} \mathrm{de}$ amilase, protease e xilanase e o complexo enzimático quatro composto por $125 \mathrm{~g} \mathrm{ton}^{-1}$ de protease e 500 $\mathrm{g}$ ton $^{-1}$ de betamananase. A suplementação enzimática não melhorou o desempenho na fase inicial e de crescimento, em razão do desbalanço nutricional, na fase de terminação proporcionou o pior ganho de peso e conversão alimentar. O rendimento de carcaça, coxa e sobrecoxa, gordura abdominal, pâncreas foram alterados pelas dietas contendo complexos enzimáticos. Os níveis de triglicerídeos influenciaram na deposição de gordura abdominal e os níveis séricos de albumina, alanina aminotransferase foram alterados pelas dietas enzimáticas. Concluiu-se que a suplementação enzimática não foi efetiva na recuperação do desempenho, rendimento de carcaça e cortes apresentando alteração no perfil bioquímico sérico de frangos de corte.

Palavras-chave: Amilase. Energia metabolizável. Protease. Xilanase.

\section{Introduction}

Corn and soybean meal are the most used ingredients in poultry diets in much of the world, and they are known to contain different anti-nutritional factors that may obstruct digestion and absorption of nutrients (YEGANI; KORVER, 2013), including carbohydrates and proteins in the digestive tract (YU; CHUNG, 2004). Corn contains non-starch polysaccharides soluble at lower concentrations than soybean meal, but its overall contribution may be substantial due to its high inclusion rate (COWIESON; ADEOLA, 2005; WEST et al., 2007).

In corn-soybean meal diets, exogenous enzymes can improve energy availability and deactivate their anti-nutritional factors (DOSKOVIC et al., 2013; STEFANELLO et al., 2016), as well as influence the health of the birds, changing the conditions in the intestinal tract and proliferation of unwanted organisms (YANG et al., 2010; YEGANI; KORVER, 2013). However, the existing knowledge about the role of enzymes is limited, controversial, or inconsistent, demonstrating that information is still needed in this area of research (OLUKOSI et al., 2007; JIANG et al., 2008; CARDOSO et al., 2011; AMERAH et al., 2016; SCHRAMM et al., 2016).

The aim of this study was to evaluate the use of diets with reduced nutritional levels supplemented with different enzyme complexes on the productive performance, carcass characteristics, cuts, and serum biochemical profile of broiler chickens from 1 to 42 days of age.

\section{Material and Methods}

The trial was conducted at the Research Center of the Western Paraná State University (UNIOESTE), Campus Marechal Candido Rondon, Parana, and approved by the Animal Experimentation Ethics Committee under the protocol no. 63/2016.

A total of 960 one-day-old male broilers from Cobb 500 lineage were used and distributed in a completely randomized design, with six treatments and eight replications, totaling 48 experimental units with 20 birds each. Two diets were formulated: positive control (PC) based on corn and soybean meal without enzyme complex, meeting all the nutritional requirements of the birds (Diet 1), and a negative control (NC) diet with reduction of $150 \mathrm{kcal} . \mathrm{kg}^{-1}$ of metabolizable energy and $12 \%$ digestible amino acids during the initial phase and $18 \%$ during the growing and finishing phases (Diet 2). Further diets were based on the NC with nutritional reductions and enzymatic supplements included as recommended by manufacturers for each rearing stage.

Four enzyme complexes were used: enzyme complex 1, composed of $125 \mathrm{~g}^{-1}$ ton $^{-1}$ protease; enzyme complex 2, composed of $100 \mathrm{~g} \mathrm{ton}^{-1}$ 
amylase, protease, and xylanase; enzyme complex 3 , composed of $500 \mathrm{~g} \mathrm{ton}^{-1}$ amylase, protease, and xylanase; and enzyme complex 4, composed of 125 $\mathrm{g}$ ton $^{-1}$ protease and $500 \mathrm{~g}^{-1}$ ton $^{-1}$ beta-mannanase. The enzymes were used following the recommendation of each nutritional matrix of the $\mathrm{NC}$ diet (Table 1 and 2). The feeding programs were based on the nutritional recommendations of the Brazilian Tables for Poultry and Swine (ROSTAGNO et al., 2011), according to the following phases: pre-initial (1 to 7 days of age), initial ( 8 to 21 days of age), growing (22 to 35 days of age), and finishing (36 to 42 days of age).

Table 1. Centesimal, energetic, and chemical composition of experimental diets.

\begin{tabular}{lcccccccc}
\hline Ingredients & \multicolumn{2}{c}{ Pre-initial } & \multicolumn{2}{c}{ Initial } & \multicolumn{2}{c}{ Growth } & \multicolumn{2}{c}{ Terminal } \\
\hline Corn & 47,95 & 59,51 & 51,48 & 63,55 & 53,18 & 66,81 & 55,43 & 67,32 \\
Soybean meal & 42,59 & 34,62 & 37,88 & 29,82 & 35,89 & 25,35 & 31,27 & 23,36 \\
Soy oil & 3,70 & - & 4,73 & 0,56 & 6,20 & 1,64 & 7,25 & 3,20 \\
Flour meat & 2,00 & 2,00 & 2,00 & 2,00 & 2,00 & 2,00 & 2,00 & 2,00 \\
Dicalcium phosphate & 1,16 & 1,20 & 1,20 & 1,24 & 1,22 & 1,28 & 1,26 & 1,30 \\
Limestone & 1,15 & 1,18 & 1,17 & 1,20 & 1,17 & 1,21 & 1,19 & 1,22 \\
Salt & 0,45 & 0,35 & 0,42 & 0,23 & 0,36 & 0,15 & 0,24 & 0,15 \\
DL-methionine 99\% & 0,37 & 0,31 & 0,33 & 0,28 & 0,32 & 0,24 & 0,28 & 0,18 \\
Biolys & 0,19 & 0,25 & 0,40 & 0,40 & 0,43 & 0,43 & 0,40 & 0,40 \\
Bicarbonate of sodium & 0,10 & 0,24 & 0,21 & 0,27 & 0,21 & 0,29 & 0,23 & 0,19 \\
Premix' & 0,30 & 0,30 & 0,14 & 0,41 & 0,23 & 0,59 & 0,41 & 0,67 \\
L-threonine 98\% & 0,04 & 0,04 & 0,04 & 0,04 & 0,04 & 0,04 & 0,04 & 0,01 \\
Total \% & 100 & 100 & 100 & 100 & 100 & 100 & 100 & 1000 \\
\hline Nutritional levels & & & & & & & & \\
\hline ME (kcal/kg') & 3000 & 2850 & 3100 & 2950 & 3200 & 3050 & 3300 & 3150 \\
Crude protein (\%) & 24,50 & 21,56 & 22,64 & 19,92 & 21,71 & 17,80 & 19,85 & 16,28 \\
Digestible Met + Cys (\%) & 10,14 & 8,92 & 9,36 & 8,24 & 8,97 & 7,36 & 8,19 & 6,72 \\
Digestible methionine (\%) & 6,96 & 6,12 & 6,39 & 5,62 & 6,11 & 5,01 & 5,55 & 4,55 \\
Digestible lysine (\%) & 13,00 & 11,44 & 12,00 & 10,56 & 11,50 & 9,43 & 10,50 & 8,61 \\
Digestible threonine (\%) & 8,45 & 7,44 & 7,80 & 6,88 & 7,47 & 6,13 & 6,82 & 5,59 \\
Available phosphorus (\%) & 4,76 & 4,76 & 4,76 & 4,19 & 13,42 & 11,00 & 4,76 & 3,90 \\
Calcium (\%) & 10,00 & 8,80 & 10,00 & 8,80 & 8,62 & 7,07 & 10,00 & 8,20 \\
Potassium (\%) & 10,02 & 8,81 & 9,21 & 8,10 & 8,81 & 7,22 & 8,00 & 6,56 \\
Chlorine (\%) & 3,24 & 2,85 & 3,05 & 2,68 & 2,69 & 2,21 & 1,96 & 1,61 \\
Sodium (\%) & 2,30 & 2,02 & 2,30 & 2,02 & 2,30 & 1,89 & 2,36 & 1,94 \\
\hline
\end{tabular}

${ }^{1}$ Premix composition: Folic acid (min) 162,50 mg; Pantothenic acid (min) 2600,00 mg; Chlorohydroxyquinoline 7500,00 mg; Copper (min) 1996,38 mg; Choline (min) 71,59 g; Ethoxyquin ( $\min$ ) 750,00 mg; Iron (min) 11,25 g; Butyl hydroxide anisole (min) 250,00 mg; Butylated hydroxytoluene (min) 756,00 mg; Iodine (min) 187.47 mg; Manganese (min) 18,74 g; Niacin (min) 7000,12 mg; Salinomycin 16,50 g; Selenium (min) 75,00 mg; Vitamin A (min) 14002,50 IU; Vitamin B1 (min) 388,00 mg; Vitamin B12 (min) 2000,05 mcg; Vitamin B2 (min) 1000,02 mg; Vitamin B6 (min) 520,00 mg; Vitamin D3 (min) 300006.87 IU; Vitamin E (min) $2500.00 \mathrm{IU}$; Vitamin K3 (min) 300,00 mg; Zinc (min) 17,50 g. 
Table 2. Nutritional matrix of the enzyme complexes.

\begin{tabular}{lcccc}
\hline Nutrients & Enzyme complex 1 & Enzyme complex 2 & Enzyme complex 3 & Enzyme complex 4 \\
\hline Crude protein (\%) & 4.000 & 5.140 & 1.719 & 1.5512 \\
ME (Kcal.kg) & 64.000 & 200.000 & 90.000 & 70.000 \\
Digestible methionine (\%) & 113 & 67 & 45 & 90 \\
Digestible cystine (\%) & 79 & 160 & 83 & 93 \\
Digestible lysine (\%) & 257 & 153 & 86 & 75 \\
Digestible threonine (\%) & 230 & 230 & 133 & 100 \\
Digestible tryptophan (\%) & 166 & 41 & 7 & 27 \\
Digestible arginine (\%) & 41 & 0 & 105 & 80
\end{tabular}

Digestible valine (\%) 204

At the end of the trial (42 days old), the broilers and feed leftovers were weighed to evaluate feed intake, weight gain, and feed conversion. Simultaneously, two broilers per plot were slaughtered by cervical dislocation and bleeding to determine the carcass yield. After scalding and manual defeathering, the carcasses were eviscerated, washed, weighed, and cut into pieces. Subsequently, the carcass, cuts, pancreas, liver, gizzard, and abdominal fat were weighed.

The carcass yield was calculated considering the dressed carcass weight in relation to the body weight of broilers, while the drumstick, thigh, chest, and wing yields were considered in relation to the weight of the eviscerated carcass. The viscera and abdominal fat were considered in relation to the live weight of broilers. The abdominal fat was constituted by the adipose tissue found around the cloaca.

At 42 days of age, after a 6-h fast, blood samples were collected from the brachial vein of two birds per experimental unit. Blood was centrifuged to obtain serum for cholesterol, triglyceride, total protein, uric acid, creatinine, alanine transferase, aspartate aminotransferase, albumin, glucose, and urea analyses using commercial kits and an automatic spectrophotometer.

330 Data of performance, yields of carçass, cuts, organs, abdominal fat, and blood parameters were submitted to analysis of variance and a Tukey test at the $5 \%$ probability level.

\section{Results and Discussion}

Tables 3, 4, and 5 show the performance during the pre-initial (1-7 days), initial (1-21 days), and growing phases (1-35 days) and the whole experimental period (1-42 days) in broilers fed PC (adequate nutritional levels) and NC diets (reduction of $150 \mathrm{kcal} \mathrm{kg}^{-1}$ of metabolizable energy and $12 \%$ of digestible amino acids during the initial phase and $18 \%$ during the growing phase and the whole experimental period) containing enzymatic complexes or not.

Feed intake (Table 3 ) did not differ between diets $(\mathrm{P}>0.05)$, demonstrating that supplementation with enzyme complexes did not meet the overestimation of the ingredients. Similar results were observed by Olukosi et al. (2007) and Yegani and Korver (2013) studying amylase, protease, and xylanase for broiler diets. The authors attributed the lack of improvement in feed intake to the low availability of substrate for enzyme activity. The same authors further suggest that corn has low pectin content and that beta-glucan values are often not reported or are negligible in this ingredient. 
Table 3. Cumulative weekly feed intake of broilers fed different enzymatic complexes ${ }^{(1)}$.

\begin{tabular}{lcccc}
\hline Diets & \multicolumn{4}{c}{ Cumulative weekly feed intake (g) } \\
\cline { 2 - 5 } & $1-7^{\text {n.s(2) }}$ & $1-21^{\text {n.s }}$ & $1-35^{\text {n.s }}$ & $1-42^{\text {n.s }}$ \\
\hline Positive control & 196,0 & 1445,1 & 3541,7 & 4300,4 \\
Negative control & 198,8 & 1471,2 & 3546,3 & 4293,5 \\
Enzyme complex 1 & 196,6 & 1452,3 & 3518,7 & 4253,0 \\
Enzyme complex 2 & 197,1 & 1462,8 & 3511,4 & 4200,0 \\
Enzyme complex 3 & 193,9 & 1455,8 & 3483,6 & 4195,3 \\
Enzyme complex 4 & 198,1 & 1479,8 & 3598,8 & 4285,9 \\
\hline SEM $^{(3)}$ & 0,682 & 6,456 & 13,432 & 13,747 \\
CV $^{(4)}$ & 2,390 & 3,123 & 2,567 & 2,108 \\
\hline
\end{tabular}

(1) Means followed by different letters in the column differ by the Tukey test at the $5 \%$ probability level,

${ }^{(2)} \mathrm{NS}$ : not significant, ${ }^{(3)} \mathrm{SEM}$ : standard error of the mean, ${ }^{(4)} \mathrm{CV}$ : coefficient of variation.

Table 4. Average cumulative weight gain of broilers fed different enzymatic complexes ${ }^{(1)}$.

\begin{tabular}{lcccc}
\hline Diets & \multicolumn{4}{c}{ Average cumulative weight gain $(\mathrm{g})$} \\
\cline { 2 - 5 } & $1-7$ & $1-21$ & $1-35$ & $1-42$ \\
\hline Positive control & $154,09 \mathrm{a}$ & $1049,20 \mathrm{a}$ & $2319,86 \mathrm{a}$ & $2836,08 \mathrm{a}$ \\
Negative control & $141,86^{\mathrm{b}}$ & $900,01^{\mathrm{b}}$ & $2032,63^{\mathrm{b}}$ & $2587,98^{\mathrm{b}}$ \\
Enzyme complex 1 & $144,20^{\mathrm{b}}$ & $908,79^{\mathrm{b}}$ & $2029,11^{\mathrm{b}}$ & $2568,55^{\mathrm{bc}}$ \\
Enzyme complex 2 & $142,77^{\mathrm{b}}$ & $891,62^{\mathrm{b}}$ & $1990,31^{\mathrm{b}}$ & $2465,50^{\mathrm{d}}$ \\
Enzyme complex 3 & $146,02^{\mathrm{b}}$ & $908,16^{\mathrm{b}}$ & $2003,80^{\mathrm{b}}$ & $2517,50^{\text {cd }}$ \\
Enzyme complex 4 $^{\mathrm{b}}$ & $145,07^{\mathrm{b}}$ & $900,94^{\mathrm{b}}$ & $2007,11^{\mathrm{b}}$ & $2469,53^{\mathrm{d}}$ \\
\hline SEM $^{(2)}$ & 0,792 & 8,508 & 17,822 & 19,303 \\
$\mathrm{CV}^{(3)}$ & 2,689 & 2,176 & 2,073 & 1,719 \\
\hline
\end{tabular}

(1) Means followed by different letters in the column differ by the Tukey test at the $5 \%$ probability level,

(2) SEM: standard error of the mean ${ }^{(3)} \mathrm{CV}$ : coefficient of variation.

Table 5. Cumulative feed conversion of broilers fed different enzymatic complexes ${ }^{(1)}$.

\begin{tabular}{lcccc}
\hline Diets & \multicolumn{4}{c}{ Cumulative feed conversion (g g) } \\
\cline { 2 - 5 } & $1-7$ & $1-21$ & $1-35$ & $1-42$ \\
\hline Positive control & $1,243^{\mathrm{a}}$ & $1,378^{\mathrm{a}}$ & $1,527^{\mathrm{a}}$ & $1,516^{\mathrm{a}}$ \\
Negative control & $1,403^{\mathrm{c}}$ & $1,635^{\mathrm{b}}$ & $1,745^{\mathrm{b}}$ & $1,659^{\mathrm{b}}$ \\
Enzyme complex 1 & $1,364^{\mathrm{bc}}$ & $1,599^{\mathrm{b}}$ & $1,735^{\mathrm{b}}$ & $1,656^{\mathrm{b}}$ \\
Enzyme complex 2 & $1,382^{\mathrm{c}}$ & $1,641^{\mathrm{b}}$ & $1,764^{\mathrm{b}}$ & $1,703^{\mathrm{bc}}$ \\
Enzyme complex 3 & $1,339^{\mathrm{b}}$ & $1,603^{\mathrm{b}}$ & $1,739^{\mathrm{b}}$ & $1,666^{\mathrm{b}}$ \\
Enzyme complex 4 & $1,365^{\mathrm{bc}}$ & $1,643^{\mathrm{b}}$ & $1,794^{\mathrm{b}}$ & $1,736^{\mathrm{c}}$ \\
\hline $\mathrm{SEM}^{(2)}$ & 0,008 & 0,015 & 0,014 & 0,011 \\
$\mathrm{CV}^{(3)}$ & 2,429 & 3,338 & 2,686 & 2,071 \\
\hline
\end{tabular}

(1) Means followed by different letters in the column differ by the Tukey test at the $5 \%$ probability level,

${ }^{(2)} \mathrm{SEM}$ : standard error of the mean ${ }^{(3)} \mathrm{CV}$ : coefficient of variation. 
The reduction in nutritional requirement $(\mathrm{NC})$, impaired weight gain (Table 4), and feed conversion (Table 5) in broilers during the pre-initial (1-7 days), initial (1-21 days), and growing phases (135 days) and supplemental enzyme complexes were not enough to restore the diet. Toledo et al. (2007) support this result in a study that evaluated the enzyme complex supplementation of broiler diets up to 35 days of age, verifying that birds require higher metabolizable energy due to lower digestive capacity. Similarly, Yang et al. (2010) and Schramm et al. (2016) attributed the inefficacy of exogenous enzymes to nutritional imbalance, which inhibits the activity of enzymes that improve nutrient degradation, digestion, and absorption.

On the other hand, during the finishing phase (142 days), the enzymatic supplementation irregularly affected the metabolism due to the nutritional imbalance in the previous periods, resulting in poor performance compared to the NC. According to Bao et al. (2013), the benefits of enzymes can be impaired when the diet does not have a good balance between nutrient composition and energy. Conversely, Stefanello et al. (2016) suggest that nutritional deficiency provides greater access for some endogenous enzymes to cell wall-bound nutrients, limiting energy utilization and nutrient digestibility.

The values of carcass, noble cuts, and abdominal fat and the relative weights of liver, gizzard, and pancreas in broilers fed diets supplemented with enzymatic complexes are shown in Tables 5 and 6 . Breast and wing yields did not differ between diets $(\mathrm{P}>0.05)$. However, the yields of carcass, thigh, and drumstick and abdominal fat (Table 6) were affected by the nutritional imbalance caused by nutritional reduction and enzymatic supplementation. According to Silva et al. (2003), the amount of energy consumed is not always sufficient to ensure the maximum protein deposition in the carcass, and a possible nutritional imbalance and an increase in net energy can contribute to the deposition of lean

tissue and the increase in carcass fat (MENDONÇA et al., 2008).

Table 6. Carcass, noble cuts, and abdominal fat yields in 42-day-old broilers fed different enzymatic complexes ${ }^{(1)}$.

\begin{tabular}{lccccc}
\hline Diets & Carcass & noble cuts & abdominal fat & breast $^{\text {ns (2) }}$ & Wing $^{\text {ns }}$ \\
\hline Positive control & $73,33^{\mathrm{b}}$ & $29,20^{\mathrm{a}}$ & $1,39^{\mathrm{b}}$ & 36,77 & 9,861 \\
Negative control & $74,01^{\mathrm{ab}}$ & $26,90^{\mathrm{b}}$ & $1,67^{\mathrm{ab}}$ & 35,79 & 9,873 \\
Enzyme complex 1 & $73,67^{\mathrm{ab}}$ & $29,01^{\mathrm{a}}$ & $1,76^{\mathrm{ab}}$ & 36,56 & 9,931 \\
Enzyme complex 2 & $74,00^{\mathrm{ab}}$ & $28,43^{\mathrm{ab}}$ & $1,72^{\mathrm{ab}}$ & 36,58 & 10,001 \\
Enzyme complex 3 & $74,76^{\mathrm{ab}}$ & $29,66^{\mathrm{a}}$ & $1,77^{\mathrm{ab}}$ & 35,61 & 9,873 \\
Enzyme complex 4 $^{\mathrm{a}}$ & $75,04^{\mathrm{a}}$ & $29,04^{\mathrm{a}}$ & $1,89^{\mathrm{a}}$ & 36,08 & 10,149 \\
\hline $\mathrm{SEM}^{(3)}$ & 0,171 & 0,178 & 0,043 & 0,229 & 0,050 \\
$\mathrm{CV}^{(4)}$ & 2,170 & 5,35 & 23,70 & 6,237 & 4,948 \\
\hline
\end{tabular}

${ }^{(1)}$ Means followed by different letters in the column differ by the Tukey test at the $5 \%$ probability level,

(2) NS: not significant, ${ }^{(3)}$ SEM: standard error of the mean, ${ }^{(4)}$ $\mathrm{CV}$ : coefficient of variation.

The relative weights of liver and gizzard did not differ between diets $(\mathrm{P}>0.05)$. In contrast, the relative weight of the pancreas (Table 7) was influenced by the enzymatic diets when compared to the $\mathrm{PC}$ and $\mathrm{NC}(\mathrm{P}<0.05)$. Possibly, the enzymatic supplementation provided an imbalance in the activity of the endogenous enzymes in the pancreas, 
corroborating with the results of Zhu et al. (2014). reduction. Moreover, the reduction in the activity of The authors associated increased pancreatic lipase (7 days old), trypsin (14-21 days of age), and pepsin (7-21 days of age) to a digestive adaptive capacity of broilers fed diets with metabolizable energy pancreatic lipase (14-21 days of age) and amylase (14 days of age) was connected to the high rate of enzyme secretion during the previous phases. Moraes et al. (2009) also observed an increase in

the specific activity of $\alpha$-amylase and lipase that was attributed to the increase in the relative weight of the pancreas.

Table 7. Relative weight of organs from 42-day-old broilers fed different enzymatic complexes ${ }^{(1)}$.

\begin{tabular}{lccc}
\hline Diets & Liver.s(2) $^{\text {n.s }}$ & Gizzard n.s $^{\text {s }}$ & Pancreas \\
\hline Positive control & 1,98 & 1,22 & $0,16^{\mathrm{b}}$ \\
Negative control & 1,85 & 1,34 & $0,15^{\mathrm{b}}$ \\
Enzyme complex 1 & 2,03 & 1,31 & $0,21^{\mathrm{ab}}$ \\
Enzyme complex 2 & 2,01 & 1,33 & $0,19^{\mathrm{ab}}$ \\
Enzyme complex 3 & 1,97 & 1,37 & $0,23^{\mathrm{a}}$ \\
Enzyme complex 4 & 2,03 & 1,39 & $0,20^{\mathrm{ab}}$ \\
\hline $\mathrm{SEM}^{(3)}$ & 0,033 & 0,019 & 0,007 \\
$\mathrm{CV}^{(4)}$ & 16,64 & 13,83 & 30,39 \\
\hline
\end{tabular}

(1) Means followed by different letters in the column differ by the Tukey test at the $5 \%$ probability level,

(2) NS: not significant, (3) SEM: standard error of the mean, (4) $\mathrm{CV}$ : coefficient of variation.
The biochemical profile of broilers fed diets containing enzymatic complexes is presented in Tables 8 and 9. The nutritional reduction and enzymatic supplementation did not affect the

enzymatic activity of aspartate aminotransferase, total proteins, creatine, glucose, uric acid, and cholesterol, which were within the normal range for broilers (SCHMIDT et al., 2007).

Table 8. Biochemical serum parameters in 42-day-old broilers fed different enzymatic complexes ${ }^{(1)}$.

\begin{tabular}{lcccccc}
\hline Diets & $\begin{array}{c}\mathrm{AST}^{(5) \mathrm{n} . \mathrm{s}} \\
\left(\mathrm{Ul}^{-1}\right)\end{array}$ & $\begin{array}{c}\mathrm{TP}^{(6) \text { n.s }} \\
\left(\mathrm{g} \mathrm{dL}^{-1}\right)\end{array}$ & $\begin{array}{c}\text { Creatine } \\
\left(\mathrm{mg} \mathrm{dL}^{-1}\right)\end{array}$ & $\begin{array}{c}\mathrm{Glucose}^{\mathrm{n} . \mathrm{s}} \\
\left(\mathrm{mg} \mathrm{dL}^{-1}\right)\end{array}$ & $\begin{array}{c}\text { Uric acid.s } \\
\left(\mathrm{mg} \mathrm{dL}^{-1}\right)\end{array}$ & $\begin{array}{c}\text { Cholesterol } \\
\left(\mathrm{mg} \mathrm{dL}^{-1}\right)\end{array}$ \\
\hline Positive control & 337,50 & 3,61 & 0,26 & 274,00 & 2,71 & $131,87^{\text {ab }}$ \\
Negative control & 337,63 & 3,17 & 0,26 & 281,12 & 2,57 & $101,50^{\text {d }}$ \\
Enzyme complex 1 & 334,50 & 3,21 & 0,24 & 273,37 & 2,86 & $111,25^{\text {cd }}$ \\
Enzyme complex 2 & 287,39 & 3,27 & 0,24 & 273,37 & 2,90 & $118,37^{\text {bc }}$ \\
Enzyme complex 3 & 371,75 & 3,39 & 0,26 & 280,50 & 2,95 & $137,12^{\mathrm{a}}$ \\
Enzyme complex 4 & 293,00 & 3,49 & 0,25 & 274,62 & 2,80 & $132,87^{\text {ab }}$ \\
\hline $\mathrm{SEM}^{(2)}$ & 9,756 & 0,051 & 0,003 & 2,771 & 0,064 & 2,592 \\
$\mathrm{CV}^{(3)}$ & 19,723 & 9,86 & 8,04 & 7,24 & 16,16 & 10,72 \\
\hline
\end{tabular}

(1) Means followed by different letters in the column differ by the Tukey test at the $5 \%$ probability level, 
${ }^{(2)}$ NS: not significant, ${ }^{(3)}$ SEM: standard error of the mean, ${ }^{(4)} \mathrm{CV}$ : coefficient of variation, ${ }^{(5)} \mathrm{AST}$ : aspartate aminotransferase, ${ }^{(6)}$ TP: total proteins.

Tabela 9. Biochemical serum parameters in 42-day-old broilers fed different enzymatic complexes ${ }^{(1)}$.

\begin{tabular}{lccc}
\hline Diets & Triglyceride $\left(\mathrm{mg} \mathrm{dL}^{-1}\right)$ & Albumin $\left(\mathrm{g} \mathrm{dL}^{-1}\right)$ & ALT $\left(\mathrm{UI}^{-1}\right)^{(4)}$ \\
\hline Positive control & $137,87^{\mathrm{a}}$ & $1,55^{\mathrm{a}}$ & $8,75^{\mathrm{a}}$ \\
Negative control & $88,75^{\mathrm{b}}$ & $1,35^{\mathrm{b}}$ & $5,25^{\mathrm{b}}$ \\
Enzyme complex 1 & $124,12^{\mathrm{ab}}$ & $1,37^{\mathrm{b}}$ & $4,50^{\mathrm{b}}$ \\
Enzyme complex 2 & $105,37^{\mathrm{ab}}$ & $1,31^{\mathrm{b}}$ & $3,75^{\mathrm{b}}$ \\
Enzyme complex 3 & $114,87^{\mathrm{ab}}$ & $1,43^{\mathrm{b}}$ & $5,12^{\mathrm{b}}$ \\
Enzyme complex 4 & $109,25^{\mathrm{ab}}$ & $1,39^{\mathrm{b}}$ & $4,25^{\mathrm{b}}$ \\
\hline $\mathrm{SEM}^{(2)}$ & 4,087 & 0,020 & 0,310 \\
$\mathrm{CV}^{(3)}$ & 22,13 & 8,51 & 27,59 \\
\hline
\end{tabular}

${ }^{(1)}$ Means followed by different letters in the column differ by the Tukey test at the $5 \%$ probability level,

(2) SEM: standard error of the mean, ${ }^{(3)}$ SEM: standard error of the mean, ${ }^{(4)}$ ALT: Alanine aminotransferase.

Triglycerides (Table 9) influenced abdominal fat deposition, carcass weight, and thigh and drumstick yields in broilers fed with enzymatic supplementation $(\mathrm{P}<0.05)$ due to the nutritional quality and quantity of the diet. According to Berchieri Júnior and Freitas Netos (2009), the energy in feed can be stored in the adipose tissue as triglycerides, and this same energy can be mobilized during feed restriction, allowing adipose tissue mass variations.

Albumin levels (Table 9) were reduced in broilers fed enzymatic diets $(\mathrm{P}<0.05)$ and were below the normal range described by Schmidt et al. (2007). According to the same authors, as the liver produces albumin, a reduction in serum concentration may cause a decrease in feed intake. Harr (2002) also attributed albumin reduction to poor digestion and absorption or loss of proteins by enteropathy and nephropathy. Therefore, the present study suggests that nutritional imbalance affected the function of albumin in transporting fatty acids, minerals, uric acid, and vitamins $\mathrm{A}$ and $\mathrm{C}$.

The alanine aminotransferase (Table 9), known to balance protein metabolism, had its activity reduced in enzymatic diets ( $\mathrm{P}>0.05)$, possibly due to the reduced metabolizable energy level. In the study conducted by Barbosa et al. (2010), higher levels of alanine aminotransferase in broilers during the first 8 days of life were observed, which were attributed to the change in dietary pattern when the broilers started to be fed diets with higher amounts of carbohydrates and proteins. The same authors observed a reduction in the activity of alanine aminotransferase in 22-day-old broilers, which was attributed to the reduction in dietary energy levels.

\section{Conclusion}

Enzymatic supplementation in diets with reduced nutritional levels did not improve broiler performance during the pre-initial (1-7 days), initial (1-21 days), and growing (1-35 days) phases. Providing diets with nutritional reduction supplemented for longer periods (1-42 days) may cause greater nutritional imbalance, resulting in increased fat deposition in the carcass, thigh, and drumstick, increased abdominal fat deposition, and alterations in triglyceride, albumin, and alanine aminotransferase levels.

\section{References}

AMERAH, A. M.; ROMERO, L. F.; AWATI, A.; 
RAVIDRAN, V. Effect of exogenous xylanase, amylase, and protease as single or combined activities on nutrient digestibility and growth performance of broilers fed corn/soy diets. Poultry Science, Savoy, v. 23, n. 1, p. 1-10, 2016.

BAO, Y. M.; ROMERO, L. F.; COWIESON, A. J. Functional pat- terns of exogenous enzymes in different feed ingredients. World's Poultry Science Journal, Sydbey, v. 33, n. 69, p. 759-774, 2013.

BARBOSA, A. A.; MORAES, G. H. K.; TORRES, R. A.; REIS, D. T. C.; RODRIGUES, C. S.; MULLER, E. S. Avaliação da qualidade óssea mediante parâmetros morfométricos bioquímicos e biomecânicos em frangos de corte. Revista Brasileira de Zootecnia, Viçosa, MG, v. 39, n. 4, p. 772-778, 2010.

BERCHIERI JÚNIOR, A.; FREITAS NETO, O. C. Salmoneloses. In: BERCHIERI JÚNIOR, A.; SILVA, E. N.; DI FÁBIO, J.; SESTI, L.; ZUANAZE, M. A. F. Doenças das aves. 2. ed. Campinas: Ed. FACTA, 2009, $1040 \mathrm{p}$.

CARDOSO, D. M.; MACIEL, M. P.; PASSOS, D. P.; SILVA, F. V.; REIS, S. T.; AIURA, F. S. Efeito do uso de complexo enzimático em rações para frangos de corte. Archivos de Zootecnia, Córdoba, v. 60, n. 232, p. 10531064, 2011.

COWIESON, A. J.; ADEOLA, O. Carbohydrases, protease, and phytase have an additive beneficial effect in nutritionally marginal diets for broiler chicks. Poultry Science, Savoy, v. 84, n. 12, p. 1860-1867, 2005.

DOSKOVIC, V.; BOGOSAVLJEVIĆ-BOSKOVIĆ, S.; PAVLOVSKI, Z.; MILOŠEVIĆ, B.; ŠKRBIĆ, Z.; RAKONJAC, S. Enzymes in broiler diets with special reference to protease. Journal World's Poultry Science, Savoy, v. 69, n. 2, p. 343-359, 2013.

HARR, K. E. Clinical chemistry of companion avian species: a review. Veterinary Clinical Pathology, Madison, v. 31, n. 3, p. 140-151, 2002.

JIANG, Z.; ZHOU, Y.; LU, F.; HAN, Z.; WANG, T. Effects of different levels of supplementary alphaamylase on digestive enzyme activities and pancreatic amylase mRNA expression of young broilers. Journal of Animal Science, Champaign, v. 21, n. 1, p. 97-102, 2008.

MENDONÇA, M. O.; SAKOMURA, N. K.; SANTOS, F. R.; FREITAS, E. R.; FERNANDES, R.; KOCHENBORGER, J. B.; BARBOSA, N. A. A. Níveis de energia metabolizável para machos de corte de crescimento lento criados em semiconfinamento. Revista Brasileira de Zootecnia, Viçosa, MG, v. 37, n. 8, p. 14331440, 2008.

MORAES, G. H. K. R.; OLIVEIRA, A. C. P.; ALMEIDA,
M. G.; TEIXEIRA, L. F.; SILVA, F. A.; LOPES, R. C. S. T. O. Perfil enzimático de $\alpha$-amilase, lipase e tripsina do pâncreas e crescimento do fígado, intestino e pâncreas de frangos de corte na fase de 1 a 21 dias de idade. Revista Brasileira de Zootecnia, Viçosa, MG, v. 38, n. 11, p. 2188-2192, 2009.

OLUKOSI, O. A.; COWIESON, A. J.; ADEOLA, O. Age-related influence of a cocktail of xylanase, amylase and protease or phytase individually or in combination in broilers. Poultry Science, Savoy, v. 86, n. 1, p. 77-86, 2007.

ROSTAGNO, H. S.; ALBINO, L. F. T.; DONZELE, J. L.; GOMES, P. C.; OLIVEIRA, R. F.; LOPES, D. C.; FERREIRA, A. S.; BARRETO, S. L. T.; EUCLIDES, R. F. Tabelas brasileiras para aves e suínos: composição de alimentos e exigências nutricionais. 3. ed. Viçosa: Universidade Federal de Viçosa, 2011. 252 p.

SCHMIDT, E. M. S.; LOCATELLI-DITTRICH, R.; SANTIN, E.; PAULILLO, A. C. Patologia clínica em aves de produção - uma ferramenta para monitorar a sanidade avícola - revisão. Archives of Veterinary Science, Curitiba, v. 12, n. 3, p. 9-20, 2007.

SCHRAMM, V. G.; DURAU, J. F.; BARRILLI, L. N. E.; SORBARA, J. O. B.; COWIESON, A. J.; FELIX, A. P.; MAIORKA, A. Interaction between xylanase and phytase on the digestibility of corn and a corn/soy diet for broiler chickens. Poultry Science, Savoy, v. 25, n. 11, p. 1-12, 2016.

SILVA, S. S. P.; SMITHARD, R. R. Effect of enzyme supplementation of a rye-based diet on xylanase activity in the small intestine of broilers, on intestinal crypt cell proliferation and on nutrient digestibility and growth performance of the birds. British Poultry Science, Edinburgh, v. 43, n. 2, p. 274-282, 2003.

STEFANELLO, C.; VIEIRA, S. L.; VRIOS, H. V.; SIMÕES, C. T.; SORBARA, J. O. B. Energy and nutrient utilisation of broilers fed soybean meal from two diferente Brazilian production áreas with na exogenous protease. Poultry Science, Savoy, v. 29, n. 7, p. 1-12, 2016.

TOLEDO, G. S. P.; COSTA, P. T. C.; SILVA, J. H.; CECCANTINI, M.; POLLETO-JUNIOR, C. Frangos de corte alimentados com dietas de diferentes densidades nutricionais suplementadas ou não com enzimas. Ciência Rural, Santa Maria, v. 37, n. 2, p. 518-523, 2007.

WEST, M. L.; CORZO, A.; DOZIER, W. A.; BLAIR, M. E.; KIDD, M. T. Assessment of dietary rovabio excel in practical United States broiler diets. The Journal of Applied Poultry Research, Champaign, v. 16, n. 3, p. 313-321, 2007.

YANG, Z. B.; YANG, W. R.; JIANG, S. Z.; ZHANG, 
G. G.; ZHANG, Q. Q.; SLOW, K. C. Effects of a thermotolerant multi-enzyme product on nutrient and energy utilization of broilers fed mash or crumbled cornsoybean meal diets. The Journal of Applied Poultry Research, Champaign, v. 19, n. 3, p. 38-45, 2010.

YEGANI, M.; KORVER, D. R. Effects of corn source and exogenous enzymes on growth performance and nutrient digestibility in broiler chickens. Poultry Science, Savoy, v. 92, n. 5, p. 1208-1220, 2013.

YU, B.; CHUNG, T. K. Effects of multiple-enzyme mixtures on growth performance of broilers fed cornsoybean meal diets. The Journal of Applied Poultry Research, Champaign, v. 13, n. 2, p. 178-182, 2004.

ZHU, H. L.; HU, L. L.; HOU, Y. Q.; ZHANG, J.; DING, B. Y. The effects of enzyme supplementation on performance and digestive parameters of broilers fed corn-soybean diets. Poultry Science, Savoy, v. 93, n. 7, p. 1704-1712, 2014. 